\title{
Consumption and income over the lifecycle in Nigeria
}

\author{
Olanrewaju Olaniyan*, Adedoyin Soyibo and Akanni O. Lawanson \\ Health Policy Training and Research Programme \\ Department of Economics, University of Ibadan, \\ Ibadan, Nigeria
}

* Corresponding author: Olanrewaju Olaniyan, Tel: +234-802-325-574l. o.olaniyan@mail.ui.edu.ng; lanreolaniyan@yahoo.co.uk

\section{Abstract}

This paper utilises National Transfer Accounts framework to estimate age profiles of consumption and income over the lifecycle in order to determine actual period of dependency in Nigeria. The paper quantifies inter-age monetary flows of consumption and labour income and subsequent economic lifecycle deficit and the implications this will have for social policy and human capital development. The results indicate that given the profiles of consumption and income over the lifecycle in Nigeria, child dependency is for the first 33 years of life while old-age dependency occurs from 63 years upwards. The period of lifecycle surplus span 30 years from 33-63 years. The structure of consumption and income flows reveals that Nigeria has a lifecycle deficit of N3.5 trillion in 2004. Since the population is highly skewed towards children, inter-generational flows are heavily skewed downwards. The deficits must then be covered through age reallocations of transfers and asset income.

Keywords: National Transfer Accounts [NTA economic lifecycle, intergenerational transfer, income age profile, consumption age profile

\section{Résumé}

Cet article utilise la méthodologie des comptes de transferts pour estimer le profil de consommation et de revenu par âge à travers le cycle de vie afin de déterminer la période réelle de la dépendance au Nigéria. Le papier mesure les flux monétaires de consommation, de revenu du travail entre les âges et le déficit du cycle de vie dérivé et analyse les implications que ceci aura pour le développement de la politique sociale et de capital humain. Les résultats indiquent que compte tenu des profils de la consommation et du revenu au cours du cycle de vie au Nigéria, la dépendance des enfants a lieu pendant les 33 premières années de la vie tandis que la dépendance des personnes âgées se produit au-delà de 63 ans. La période de surplus de cycle de vie se situe entre 30 ans de 33-63 ans. La structure des flux de consommation et de revenu indique que le Nigéria a un déficit de cycle de vie de N3.5 trillion en 2004. Compte tenu du fait que la population est à forte asymétrie vers des enfants, les flux inter générationnels sont fortement biaisés. Les déficits doivent alors être couverts par des redistributions 
entre les âge des transferts et du revenu de capitaux.

Mots-clés: Comptes de transfert nationaux $[N T A[$ cycle de vie économique, transfert entre générations, profil d'âge de revenu, profil d'âge de consommation

Revised: January 2011

\section{Introduction}

The shape of economic lifecycle is important to economic development and social policy. Life cycle is a longitudinal concept referring to the passage through life of an individual or a generation [Lee and Mason, 2008 $\square$ and the economic behaviour over the lifecycle can be summarised by the amount consumed and produced through labour at each age. The relationship between these two reflects economic dependency which occurs when consumption exceeds labour income. The human life cycle has two stages of dependency which are the childhood and old-age. These dependency periods are separated by a long period of surplus production. The dependent age groups are sustained by the flows of resources from the productive age group. The flows can be upwards or downwards Lee 1994 $\square$ Redistribution of resources across age has always been centrally important throughout human history. Although the circumstances have changed over time, the reallocation of resources across age groups is an important feature of an economy but it has gone largely unmeasured for many economies [Mason et al. 2009]

There had been a plethora of studies investigating the relationships between population age structures in relation to economic change Renteria et al., 2009; Racelis et al., 2007; Mason
2007. These specifically concern the ages during which people are dependent and whether the extent of that dependency varies in important ways by the age of dependents. Relatively little is known, however, about the ages during which people are dependent and whether the extent of that dependency varies in important ways by the age of dependents. Estimates of the economic lifecycle can be used to answer these questions and, more importantly, to assess how public policy influences the economic lifecycle.

Nigeria is the most populous country in Africa and the 2006 national census puts her population at 140 million people. This makes Nigeria's population to be more than 20 per cent of the African population. This implies that an understanding of the economic lifecycle in Nigeria has important implications for Africa as a whole. Nigeria's population is however young. In the next few years however, the country is expected to experience a shift from very young population structure to one where there is a shift towards youths and working age population. All these will determine the standard of living in the country. Evidences have suggests that poverty has reduced considerably from 65.7 percent in 1996 to 54.5 per cent in 2004. Despite the reduction in poverty incidence, the number of people living in poverty has been on the increase, 
For example NBS [2005 $\square$ reveals that the number of people living in poverty increased from 66 million in 1996 to 78 million in 2004 despite a decrease in headcount ratio from $67 \%$ to $54 \%$.
This is driven mainly by the increase in population whose rate is about $2.4 \%$ per annum during the period 2000 2008 TTable I $\mathrm{C}$

Table I Population Growth Rate in Nigeria

\begin{tabular}{|c|c|c|c|}
\hline & $1970-1990$ & $1990-2000$ & $2000-2008$ \\
\hline Population annual growth rate $\$ \% \square$ & 2.7 & 2.5 & 2.4 \\
\hline $\begin{array}{c}\text { Average annual growth rate of urban } \\
\text { population }[\% \square\end{array}$ & 4.9 & 4.4 & 4.0 \\
\hline
\end{tabular}

Although the average population growth rate in the country has been declining, the country is increasingly becoming more urbanised as the growth rate of urban population was 4.0 percent during the same period. The high population growth rate is a consequence of the high total fertility ratio in the country. Fertility ratio was still as high as 5.85 in 2000 [Table 2] This is expected to fall to 4.74 in the current year 2010 and 2.4 in 2050 United Nations, 2007. Total age dependency is very high and by 1990, it reached its highest rate of 96 percent. It has been projected that this will reduce to $85 \%$ in 2010 and 45 percent by 2050.Life expectancy in Nigeria was low at just 46.6 years in 2005. It is however expected that it will increase to about 62.1 years in 2050 .

Table 2 Trends of dependency rate and total fertility ratio $\square$ TFR $\square$ in Nigeria

\begin{tabular}{ccccc} 
Year & \multicolumn{3}{c}{ Dependency rate [percent } & \multirow{2}{*}{ Total fertility ratio } \\
\cline { 2 - 3 } & Total & Child & Old-age & \\
\hline 1970 & 90 & 84 & 6 & 6.9 \\
1980 & 91 & 85 & 6 & 6.9 \\
1990 & 96 & 91 & 6 & 6.6 \\
2000 & 93 & 88 & 6 & 5.9 \\
2010 & 85 & 80 & 6 & 4.7 \\
2020 & 74 & 68 & 6 & 3.6 \\
2030 & 62 & 56 & 6 & 3.0 \\
2040 & 54 & 47 & 7 & 2.6 \\
2050 & 50 & 41 & 9 & 2.4 \\
\hline
\end{tabular}

Source: UN [2007] 
Results from many previous studies have emphasized this dependency and have used dependency ratios or other crude measures of population age structure in relation to economic change [Bloom et al., 2010[. Relatively little is known, however, about the ages during which people are dependent and whether the extent of that dependency varies in important ways by the age of dependents. Estimates of consumption and labour income over the economic lifecycle can be used to answer these questions. In recent years researchers have focused on the relationship between income and consumption profiles of individuals in different age groups and how it determines the economic lifecycles of nations. This is because income and consumption age profiles provide more detailed and richer information about the lifecycle and economic dependency QQueiroz and Turra, 2010; Mwabu and Muriithi, 2009 Some have utilized the National Transfer Accounts $\square$ NTA $\square$ framework for their analysis especially in more than 30 countries INTA 2010 The NTA framework is an accounting system for measuring intergenerational transfers at the aggregate level in a manner consistent with National income and Products Accounts [NIPA. This paper therefore utilises the NTA framework to estimate the income and consumption of different age groups in Nigeria and the subsequent economic lifecycle of Nigeria and based on the estimates suggests policy implications for promoting human capital development and social policy in Nigeria. The next session presents the literature review and theoretical framework followed by the data and methods in section 3 . In sec- tion 4, the main findings of our analysis are presented. Discussions and Conclusion are provided in Sections 5 and 6 respectively.

\section{Literature review and theoretical framework}

The human life cycle begins and ends with dependency Lee, 1994[. These ages of dependency vary considerably with economic development. Specifically, child dependency lasts longer and old-age dependency begins earlier in higher income countries. The changes in age structure that result from the demographic transition have economic consequences. They also have direct effect on standard of living by influencing the nature of population in the working ages. Recent studies are beginning to define dependency based on the structure of consumption and income over the lifecycle and not on the working age population Lee and Mason, forthcoming 2010

In most settings, children are unable to support themselves until they are in their mid-teens to early twenties, and the elderly gradually lose their ability to support themselves as they experience the disabilities and diseases associated with normal aging. A substantial proportion of any human population thus consists of dependents, individuals who are not fully independent, economically. Because the periods of dependency occur at the beginning and end of the life span, the shape of a population's age structure determines its dependency burden, that is, the number of workingage adults relative to the number of children and the elderly Q Queiroz and Turra 2010

The understanding of the flows of 
consumption and labour income is important in understanding the economic lifecycle. Lifecycle deficit refers to the difference between labour income and consumption. The economic lifecycle refers to the cross-sectional age patterns that gives a picture of the actual age at which individuals reach economic independence or fall back into dependency [Lee et al. 2006] In addition to this it shows the peak ages of income or the development of consumption at older ages which can have important policy implications.

The theoretical analysis of reallocation of resources across different ages and transfers, in particular, has been done under many frameworks in the economic literature. A common framework that is often utilised is the overlapping generations models [OLG framework. The OLG framework presents economic activities that take place where different generations of people coexist and make some kind of deals with one another. It is a response to the seminal works of Samuelson

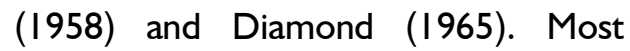
advanced macroeconomics textbooks now explore macroeconomic theory from OLG framework. The framework has been used in analysing optimal population growths, economic fluctuations among others. Dowever, most of the analysis based on OLG framework makes many strong assumptions that are difficult to rationalise in national economic systems. For example, some of the models make the assumption that life cycle is divided into two broad age groups which do not include the child dependency age-group. This assumes that life cycle starts at labour market entry and ends with old age dependency [Lee 1994] This compromises the adequacy of policy prescriptions from such models because child dependency is an important stage of the economic lifecycle. This is because children can be costly in times of child birth and childrearing, which broadly defined, can include the period of higher education of children. In order to address some of the issues raised by the omission of children from OLG framework, Becker and Murphy $\square 988 \square$ developed a theory linking parental transfer decisions to the development of the welfare state. They submit that there is a socially optimal amount of investment in children in which parents' adequate investment in the education of children would be made up to the point where the rate of additional year of education would equal to the rate of return on an additional unit of capital.

A more comprehensive way of dealing with intergenerational coexistence, and transfers within the economic lifecycle is by using the NTA framework. NTA is an accounting system for measuring intergenerational transfers at the aggregate level in a manner consistent with National Income and Product Accounts Bommier and Lee, 2003; Lee, 1994] The NTA approach works through the construction of an age-specific national economic input-output system. The accounts allocate consumption and production to single years of age. Thus, they facilitate understanding of how changes in a population's age structure, a product of changes in fertility and mortality, potentially affect the extent to which there is a surplus of production over consumption and hence a potential for understanding the struc- 
ture of life cycle deficits across age groups and how these deficits can be financed. NTA offers a unique way of examining population development links. It gives the interaction between, and among population age structure, economic lifecycle and the system for intergenerational supports and their potential implications on the accumulation of wealth, economic growth and generational equity [Lee and Mason et al., 2010[ The economic flows are measured across age groups in a systematic and comprehensive way, and identified by the economic mechanisms and mediating institutions. Many studies including Soyibo et al., 2008, Dramani. [2010]and Mwabu and Muriithi, [2009] have applied the methodology to different countries in Africa.

\section{Data and methods}

\section{Methods}

The methodological framework utilised in this paper is motivated by the National Transfer Accounts methodology. The process of estimating the age profile of consumption and income is the basis for the economic lifecycle deficit equation in the model. Life-cycle deficit Wwich is the difference between consumption and labour earnings at each age $\square$ is defined as in equation I.

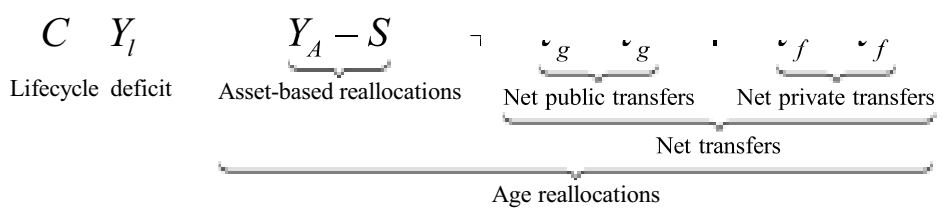

The equation states that lifecycle deficit is financed by a combination of net transfers and asset based reallocations. In the framework, inflows to individuals of any given age consist of labour income $Y$, income from assets $\square_{A}$ ), and transfer inflows from the public sector $\Psi_{g}^{+} \square$ and private sector $\square_{f}^{+} \square$ Outflows consist of consumption [C] investment $\square$ [in capital, credit and land, and transfer outflows to the government $\square_{\mathrm{g}} \square$ and to the private sector $\square_{\mathrm{f}} \mathrm{G}$ The equation above is obtained by rearranging terms in the basic Inflows = Outflows identity and by noting that saving $S$ equals investment $I$. Thus, the equation $\square$ asserts that the difference between consumption and production, known as the lifecycle deficit, must necessarily be equal to age reallocations made up of asset-based reallocations and net transfers. This paper provides estimates of $L C D$ made up of differences in consumption and labour income allocated by age group only. This is based on the fact that the economic lifecycle measures how consumption, labour productivity, and economic dependency vary with age.

In order to construct the consumption and labour profiles by individual age groups, we used the methodology used in constructing national transfers accounts proposed by the Lee and 
Mason [2010 and described in several studies including Mason [2007] As a result of the importance of human capital in aggregate consumption in the economy, we define total consumption as comprising health consumption, education consumption and other consumption. Per capita consumption and labour income for each age group is then computed from the survey data using direct methods. In the case of the income profile, two types of income were identified. In the case of consumption by individuals in different age groups, we also construct different profiles for each component of consumption Thealth, education and other? separating between public and private consumption. The age profile of the private education expenditure was computed from the expenditures of individuals enrolled by type of educational institutions by age and levels. Dence private education consumption of individuals are determined to be private expenditure on education. In the case of public expenditure we utilize figures from government's recurrent and capital expenditure for the year in the different levels of educational institutions in the country. This expenditure is then combined with age-specific enrolment rates in the country to determine government expenditure on education by age.

$\square$ ealth consumption is calculated in a similar way to that of education. Private consumption is calculated as the individual expenditure on health by age as reported in the NLSS survey data. Government spending on health however is calculated from the recurrent and capital expenditure of government in health for the reference year. This was then combined by the health facility utilization rate by age of the individual and disease incidence. The public health consumption data is then triangulated with the figures from the National $\square$ ealth Accounts of Nigeria. After computing the education and health profiles, the "other" category includes general public services, defence, public order, administrations, economic sectors etc. The private "other" expenditure is computed from the profile of other expenditures reported in the survey by individual age. $\square$ owever, in the case of other public consumption, the residual of public expenditure less education and health expenditure are allocated equally to all the age groups.

Labour income is derived from two components which are wage earnings and self-employment income. The wage income is determined to be wage earnings of those who are employed while the self employed income was determined as the income of entrepreneurs as well as self employed persons in the country. The per capita age profile was then determined using the survey data. Both earnings and self employment income profiles were derived from the survey data

After computing the different age profiles, they were adjusted to their corresponding macro control to be consistent with the National Accounts figures. The approach of using the aggregate control is to allow for the allocation of expenditure estimates by age profile in such a way that whatever estimates are obtained from various sources like surveys, for example, are consistent with corresponding estimates in NIPA as reported in NBS [2007] The aggregate control for the 
earnings and self employed is chosen as Compensation of workers and mixed income respectively. The mixed income is calculated as $60 \%$ of total operating surplus given the large informal sector in Nigeria.

\section{Data}

The NTA estimates presented in this paper were constructed using data from various sources. The computation of the age profiles from micro level survey data comes from the 2004 National Living Standards Survey [NLSS $\square$ [NBS, 2005. The 2004 NLSS is the first Living standard survey in Nigeria and is based on a representative sample of households in Nigeria. The survey contains detailed accounts of income by source, expenditure by function and consumption by type. In all, the survey contains information for more than 21, 900 households and 90,000 individuals. The aggregate control data for making the per capita age profile estimates consistent with the 2004 national income accounts figures is derived from the National Income Accounts \$pecifically Income and Outlays breakdown $\square$ of the country [NBS, 2007 Both data above were provided by the National Bureau of Statistics [NBS $\square$ The population figures were obtained from the UN Population Database [hational population in single ages[United Nations, 2007[.

\section{Results}

Consumption and income profiles determine the economic lifecycle of the country. Most countries always have lifecycle deficit since labour income alone cannot offset all consumption expenditure within the economy. Our results show the components are Con- sumption and Income in the country, while lifecycle deficit LCD is estimated as the difference between the two at each age.

\section{Consumption}

Total consumption is reported for both the private and public sectors. For each of the sectors, consumption is further divided into three components: consumption on health, education and other commodities and services. This is because total consumption does not tell the whole story, the interesting part being an understanding of the proportion that the public sector contributes vis-a-vis the private sector. The consumption profiles of Nigeria share a similar pattern with the profile of many other countries reflecting a steep rise during childhood with relative stability among working adults and the elderly Figure IT. The results further show that at the aggregate, while consumption tends to increase with age, rising rapidly between age zero and $2 I$, it appears to flatten out in the working age years, sloping upward gently in the early elderly years, before declining later. Per capita consumption profile indicates that Nigerians spend more on per capita basis on health than on education, except for the age range between 12 and 24 . This is expected because the age group is the range when education expenditure is much intensive. There is very little consumption of education before age 5 and beyond age 35 in Nigeria. Expenditure on education increases rapidly until age 17 when expenditures start to decline. 


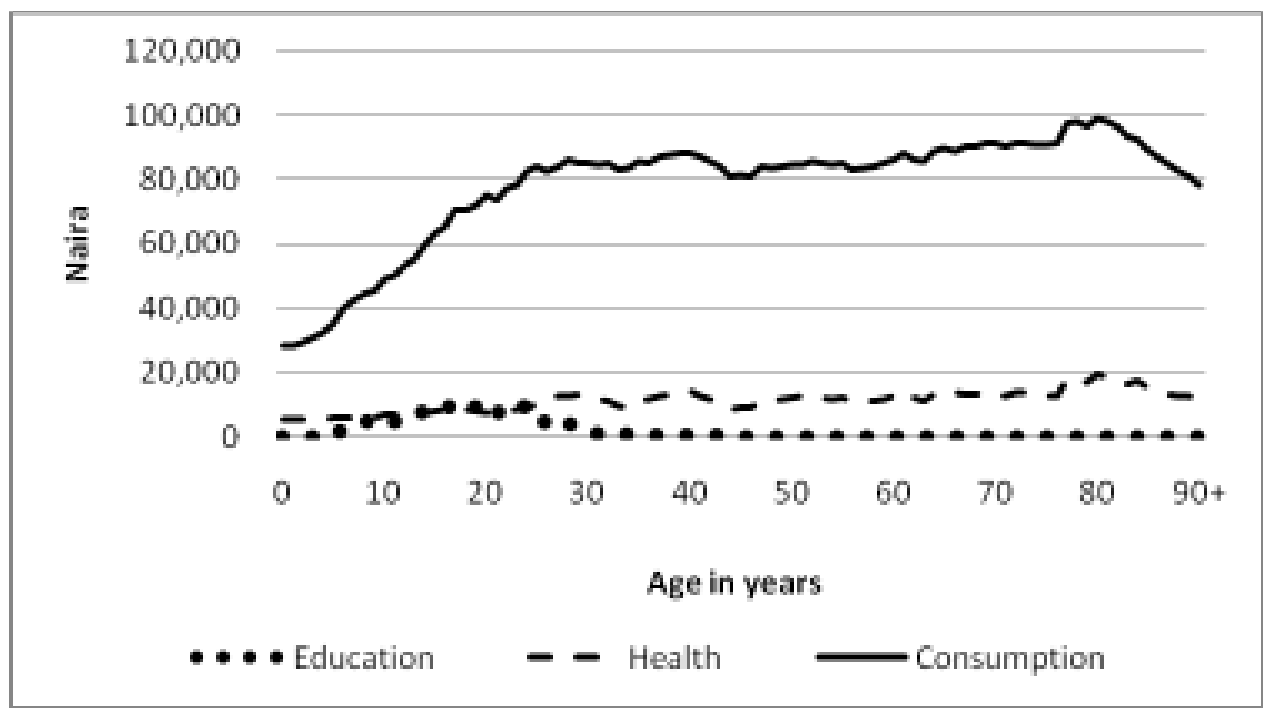

Figure I Age profile of per capita consumption in Nigeria

The peak spending on education is, however, by age 20 years old. Per capita other consumption appears to vary a little after age 30 where it stopped its initial rapid increase. The age-span during which Nigerians consume education is also quite long: from age 4 to over age 40. Despite this, the amount of spending on education is quite low to what obtains in some East Asian countries. For example while Indonesians spend about 5 to 7 percent of the average labour income on education, Nigerians spent 3.2 percent on education. Even with this, government accounts for less of 10 percent of this education consumption unlike some developed countries where government accounts for most of the expenditure in education. For example private sector accounts for just 0.7 percent of expenditure on education in Germany KKluge, 2009?

Figure 2 presents the age profile of human capital consumption. The figure reveals that private sector spends more on human capital on the average than the public sector. In particular, Figure 2 shows the dominance of the private sector in educational expenditure. Although the Nigerian government introduces a Universal Basic Education [UBE $\square$ in Nigeria in 1999 where basic education is free and compulsory for the first nine schooling years, it has not significantly reduced the amount of funds spent by the private sector on education. Individuals and households have been spending more on education however, because it is tuition-free only. The private sector still has to spend a lot on textbooks and other educational materials. In addition, many parents provide extra lessons after school which they have to pay for DOlaniyan, 2009 Furthermore there is a growing population of children who attends privately owned educational institutions 
from primary to tertiary institutions. Besides, there is no national scholarship funding for the poor or any groups of individuals, for that matter, in the coun- try. This makes private expenditure on education to be rather high and perhaps, unbearable particularly for the poor.

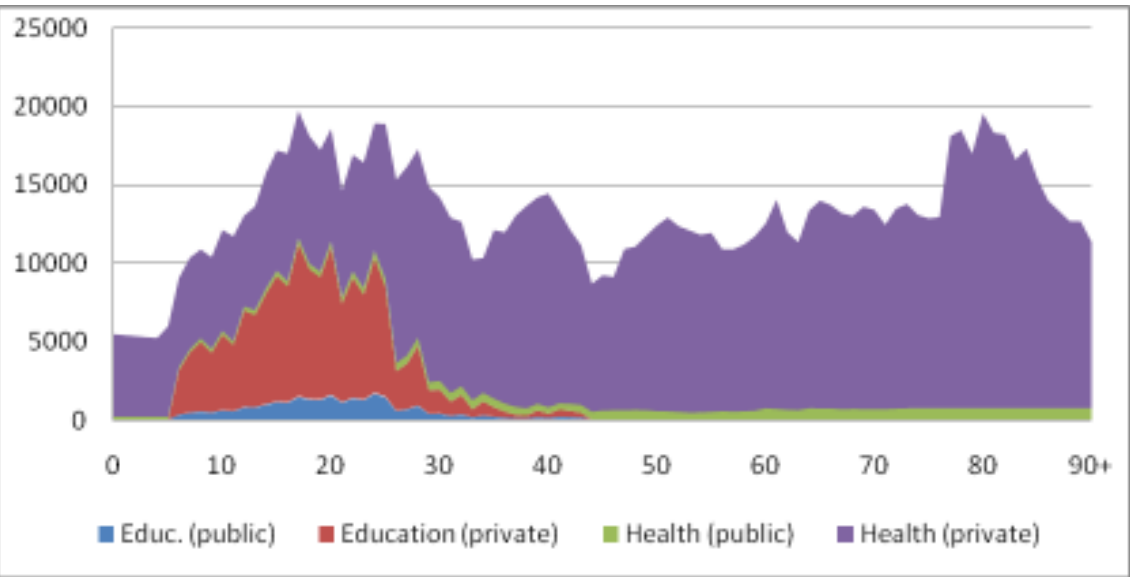

Figure 2 Age profile of per capita human capital consumption, Nigeria 2004

Our result also indicates that $20 \%$ of total labour income was spent on health in Nigeria with a larger proportion of health spending in Nigeria accounted for by the private sector. This is a result that is consistent with earlier studies on health expenditure in Nigeria which indicate that the private sector have a more than proportionate health spending in the country [e.g. Soyibo et al., 2009

\section{Labour income}

Labour income comprises earnings and self-employment income, Labour income has an inverted- $U$ shape reflecting the fact that production is concentrated among the working-age adults. In most countries, the peak in productivity is reached somewhere between ages 40 to 50 Mason et al., 2009] The labour income profile for Nigeria in
2004 follows the usual pattern of being bell shaped. There is however a bump around age 60-65. One reason for this is that when people retire from formal jobs, most Nigeria only transit into self employment which accounts for a less rapid decline of labour income beyond age 62. In Nigeria however, labour income peak at age 46 years [ligure 3[ Unlike many developed countries, self employed income accounts for 76 percent of all labour income in Nigeria and it is bigger than wage earnings for all ages. This is not surprising as most Nigerians are working in the informal sector where they are likely to be self employed. Thus their income surpasses the income of wage earners. 


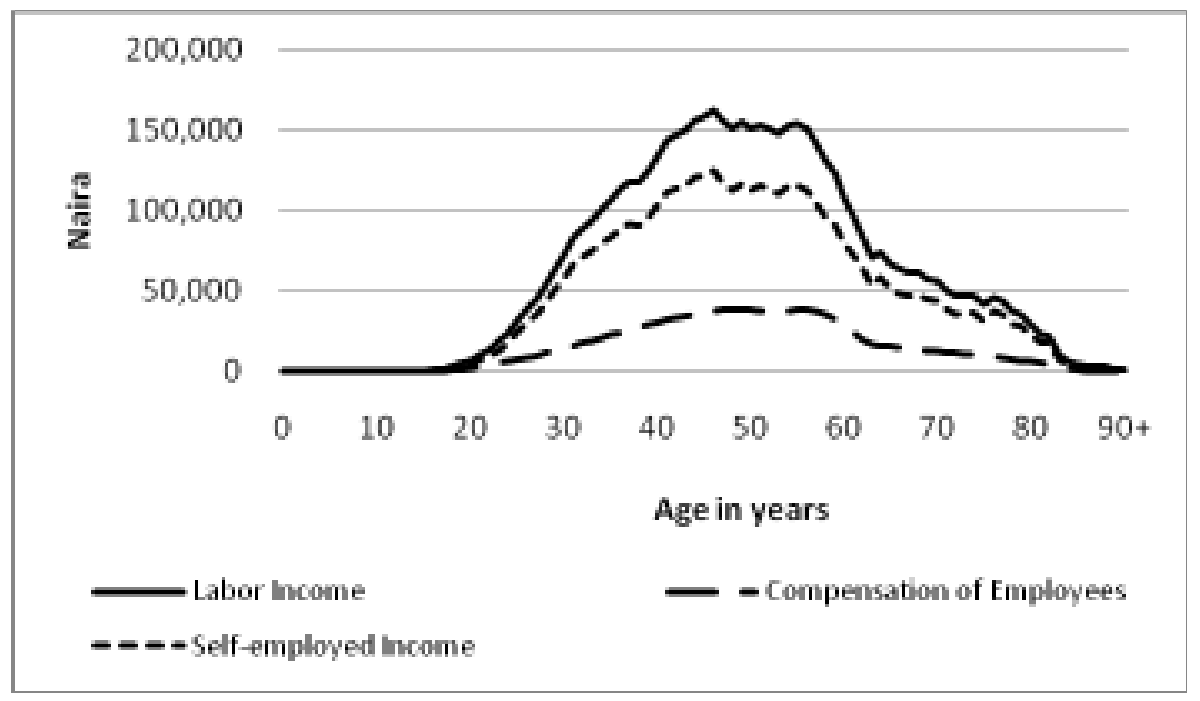

Figure 3 Age profile of components of per capita labour income, 2004

\section{Lifecycle deficit}

The relationship between income and consumption reveals whether the country has an economic lifecycle deficit or surplus. The economic lifecycle deficit ILCD $\square$ is measured by the difference between consumption and labour income at each age which gives us an empirically-based, continuous measure of economic dependency. It should be noted that the differences in consumption and labour income are influenced by differences in their components. Figure 4 presents the per capita values of lifecycle deficit in Nigeria. The figure reveals that lifecycle deficits exist for the young between ages 0 and 33 years and while it exists for the elderly between ages 63 and above. Nigerians only experience surplus between ages 33 and 63 years when labour income exceeds consumption for the different ages. Incidentally, the combination of the deficits outweighs the surplus period.

The result is consistent with most other studies in that the economic lifecycle in Nigeria is characterised by three stages, which are the youth dependency stage followed a period of economic surplus and then elderly dependency in the later stage of life.

Our results indicate that Nigeria enjoys an economic lifecycle deficit of 3.5 trillion Naira in 2004 . About $90 \%$ of the deficit is accounted for by child deficit which is much greater reflecting the preponderance of younger people in its population. The peak for the per capita deficit occurs for children aged 17 years and for the elderly it occurs at age 86 . $\square$ owever, the highest per capita surplus occurs at the age of 46 years.

\section{Discussion}

Consumption expenditure in Nigeria is 


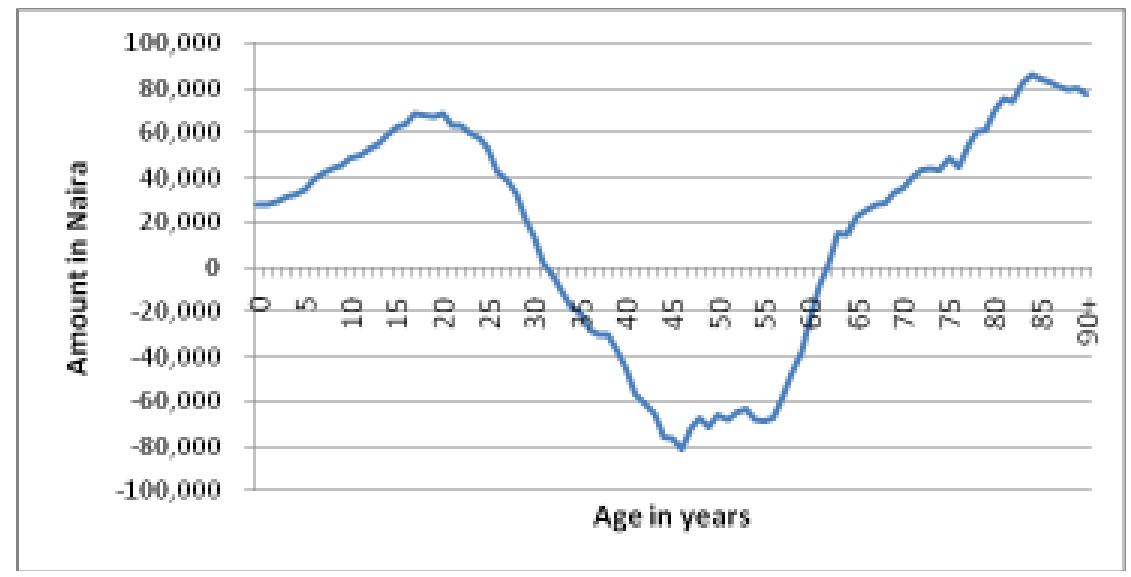

Figure 4 Per capita lifecycle deficit, 2004

predominantly from private sources. Therefore, the burden of building human capital is unfairly skewed against the poor. The poor need to be relieved of this additional and perhaps unnecessary burden. One interesting finding is the low government expenditure on human capital within the economy. Public consumption of health and education amounts to low percentages of household expenditures, whereas the private sector bears nearly all of the associated costs. Low government expenditure on education is not surprising given the relatively low enrolment rate in primary education, for example, compared to countries like Kenya. The same high proportion of consumption by the private sector also exists for health. This is consistent with the results of the Nigerian National $\square$ ealth Accounts [see Soyibo et al., 2009].

The study thus implies that government will need to be more alive to its stewardship role as it is the case even in less endowed African countries, like
Kenya. The period of child dependency is longer in Nigeria than in many countries. Dowever, the period of old age dependency is shorter in Nigeria. These imply the need to have appropriate social policies to improve the quality of life of both the young and the old so that Nigeria can begin to reap from its investment on her children very early and the elderly can have comfortable and less stressed life in old age.

The labour income profile for Nigeria shows that most of the income is earned by the working age group of the population. The total labour income earned in the country is however less than the total consumption by the population leading to lifecycle deficit. The first implication of the age profiles of the lifecycle deficit is that given the individual lifecycles in Nigeria, the young and the elderly consume more than they produce. In Nigeria, the ages for which an average Nigerian enjoys lifecycle surplus span 30 years between ages 33 years when income exceeds con- 
sumption and age 63 years when consumption once again exceeds income.

This period shows empirically the actual dependency period in Nigeria. Compared to other countries, the period marking the end of childhood dependency is late. For example, in China, Germany and India, childhood dependency ends at age 21, 27 and 26 years, respectively. The age for Nigeria however compares effectively with other countries in Africa with Senegal, South Africa and Kenya having child dependency ending at ages 35,33 and 29 years, respectively. The late end to child dependency in many African countries has been argued to be a result of late enrolment in schools which makes many of them end school late. In addition, many of these countries including Nigeria have a high unemployment and underemployment rates.

In Nigeria, the surplus period is for 30 years. This is however lower than the surplus period for most Asian countries at 37 years, 35 and 34 for China, India and Indonesia respectively. This is contrast to some other countries whose surplus periods are lower than Nigeria. These countries include Brazil, Kenya and Senegal surplus periods of 20, 26 and 25 years respectively. Even with a surplus period of 30 years, the surplus generated during the period was just NI.4 trillion which is not enough even to cover half of the child deficit. The implication is that Nigeria must rely on asset income and transfers to be able to finance consumption of all age groups.

It should also be noted that the surplus period also ends later than in other countries. While it ends at age 63 in Nigeria it ends much earlier at age $6 \mathrm{I}$,
60 and 59 for India Indonesia and Kenya respectively [Mason 2008? The reasons for the late end to surplus can be traced to late retirement in Nigeria. The official retirement age in the country is 60 years. This is however limited to the small fraction of the population that is employed by government or formal sector. Since most of the people are in the informal sector, they continue working as they do not retire. In addition, most people who work for government also only retire from government employment and then start their own business because of the failure of the government pension system which does not guarantee pension payment to the elderly.

The second implication from the lifecycle deficit is that there must be some age reallocations from the surplus ages to the deficit periods. Figure 4 shows the age profile of the per capita lifecycle deficit in Nigeria. The graph indicates that the deficit has to be offset by those with surplus. Although, a look at the per capita values of the deficit might indicate a near equal proportion of children and elderly lifecycle deficit, however, the young population of Nigeria in 2004 shows that intergenerational flows to offset the deficits in Nigeria definitely weigh heavily downwards, i.e. in nominal aggregate terms a lot more is spent on the young than the old. This structure is in line with what obtains in some other African countries such as Kenya \$\$oyibo et al., 2008 and Mwabu and Muriithi, 2009 As a result of the lifecycle deficit it means that resources must be transferred from the surplus age groups to the deficit age groups. In per capita terms, the transfer to the elderly peaks at over $\mathrm{A} 80,000$ in 
2004 at age 86. In contrasts, the per capita LCD for children peaks over N60, 000 around age 17 years.

Inter-generational flows in Nigeria are heavily skewed downwards and LCD is much higher than lifecycle surplus, suggesting that extra consumption is funded from asset income and transfers from abroad. This suggests that there is need to provide incentives to enhance the building and generation of asset income as well as transfers from abroad. The results of the study thus offered some implications for policy. First, improving income generation in Nigeria will need to take into account the informal sector, while not ignoring the formal sector. In this connection, policies directed at employment generation, entrepreneurship and innovation development like the establishment of the Small and Medium Enterprises Agency of Nigeria [SMEDAN $\square$ and the National Programme for the Eradication of Poverty [NAPEP $\square$ will need to be strengthened. Besides, the economic policy climate must give appropriate incentives for employment in the formal sector to grow.

\section{Conclusion}

This paper has attempted to provide the age profiles of income and consumption of Nigerians over the lifecycle using cross-sectional data of 2004.The results reveal that during the year, Nigeria experienced lifecycle deficit. Labour income in Nigeria is predominantly from self-employment which is mostly in the informal sector. This suggests that to boost labour income, appropriate incentives including building and developing institutions that will increase productivity of self employed persons should be given the attention they deserve. Besides, the share of formal sector employment needs vigorous boosting, in the medium to long-term in the country.

Surplus from labour income is not enough to cover all the deficits and as such, the remaining lifecycle deficit must be covered from public and household transfers as well as asset incomes. Although transfers is important for the elderly and children, some studies have shown that the importance of government transfer flows to the individuals is very low \$oyibo et al., 2010. Although the elderly might rely on assets and dissaving, the children has no such asset and thus has to rely on familial and other private transfers. Dence, there is need to improve the vehicle for building human capital in Nigeria. Policies aimed at reducing the burden of the poor in human capital building in health and education is important in this regard. Accordingly, there is need to improve government expenditure on education and health. In education, improving the flow of funds from government to its citizens through scholarships and bursaries, and loans can lighten the burden on the poor. In health, transfers to the poor through well-operated drug revolving funds will need to be intensified'. Besides, the resource-pooling and risk-pooling functions of health financing using health insurance Wwich now exists in the country $\square$ and perhaps earmarked taxes

I. We acknowledge that some drug revolving fund schemes exist in a number of states in Nigeria. While casual empiricism suggests that the contribution may be small, the perennial problem of lack of data makes it difficult to estimate the value. 
need being strengthened. In the case of health insurance because of the large informal sector, there is the possibility of excluding a large segment of the population if it is not extended to informal sector. It is therefore, important that the implementation of the informal sector health insurance which has already been designed be expedited to cover as many Nigerians as possible.

Improving child dependency in Nigeria requires improving child human capital development in education and health. Thus, health policies aimed at boosting child health in the area of immunization, among others require strengthening. In education, boosting school enrolment, particularly at the primary and secondary levels, is key. To improve adult dependency, social protection policies like social security and pension schemes require enhancement and strengthening. The establishment of the National Pensions Commission is one such policy. Dowever, there is need to develop a similar policy for the informal sector.

\section{References}

Becker, G., Murphy, K., 1988. "The Family and the State" Journal of Law and Economics 21

Bloom D., J. Finlay, S. Dumair, A. Mason, O. Olaniyan and A. Soyibo [2010] Prospects for Economic Growth in Nigeria: A Demographic Perspective: Paper presented at the IUSSP Seminar on Demographics and Macroeconomic Performance held at Novotel, Gare de Lyon, Paris, France 4-5 June 2010

Bommier, A. and R. D. Lee 2003. "Overlapping generations models with realistic demography." Journal of
Population Economics 16: 135-160.

Diamond, P. 1965. National Debt in a Neoclassical Growth Model. The American Economic Review,

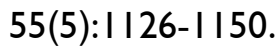

Dramani, L. [2010 $\square$ Gender in NTA Accounts: Case of Senegal: unpublished manuscript.

Kluge, F. A. 2009 Transfers, Consumption and Income over the lifecycle in Germany; MPIDR Working Paper WP 2009-14, Max Planck Institute for Demographic Research, Rostock, Germany

Lee, R 2005 Demographic Change, Welfare and Intergenerational Transfers: A Global Overview. Paper prepared for Recontres Sauvy at Villa Mondragone, Frascati, Rome

Lee, R. D. 1994. Population, Age Structure, Intergenerational Transfers, and Wealth: A New Approach, with Applications to the US. Journal of Human Resources. XXIX: 10271063.

Lee, R., Lee, S., and Mason, A. 2006. Charting the Economic Life Cycle. In Population Aging, Human Capital Accumulation, and Productivity Growth, pages 208-237. Edited by A. Prskawetz, D. E. Bloom and W. Lutz., New York, Population Council.

Lee, Ronald and Andrew Mason, eds. 2010 forthcoming. Population Aging and the Generational Economy Edward Elgar $\square$

Mason, A. 2007. "The Economic Life Cycle and Population Age Structure" Substantive Report of Work accomplished during the $38^{\text {th }}$ Summer Seminar on Population Workshop on Population, Development and Policy: The 
Economic Payoff of Population Change.

Mason, A. 2008. Lectures and Presentations at the Seminar on Population, Development and Policy: A Follow-Up Workshop, $39^{\text {th }}$ Summer Seminar on Population and Development, East-West-Centre, $\square$ onolulu, $\square$ awaii. 3 June-3 July

Mason, Andrew, Ronald Lee, An-Chi Tung, Mun-Sim Lai, and Tim Miller, [2009] "Population Aging and Intergenerational Transfers: Introducing Age into National Accounts", in Developments in the Economics of Aging', Edited by David Wise, National Bureau of Economic Research: University of Chicago Press $\square$

Muriithi, Moses and Germano Mwabu 2009. Estimation of National Transfer Accounts for Kenya Using 1994 Data: Selected Results and Discussion of their Policy Implications Paper presented at the XXVI IUSSP Conference Marrakesh 27 Sept - 2 October

NBS [National Bureau of Statistics]. 2007. National accounts of Nigeria, 198I-2006. Abuja: NBS

NBS [National Bureau of Statistics]. 2004. Poverty Profile for Nigeria Abuja: NBS

NTA [National Transfer Accounts $\square$ 2010. National Transfer Account website. $h t t p: / / w w w . s c h e m e a r t s . c o m /$ proj/nta Accessed 10 April 2010

Olaniyan, O 2009. Parental Efforts and Education production in Public and Private Schools: Evidence from Primary School Children in Low Income Areas of Lagos, Nigeria; Paper presented at the CSAE Conference on Economic Deve- lopment in Africa held at St Catherine College, University of Oxford, Oxford, UK, 22-24 March,

Queiroz, B. L. and C. M. Turra 2010. Window of Opportunity: Socioeconomic Consequences of Demographic changes in Brazil paper presented at the IUSSP seminar on demographics and Macroeconomic Performance, Paris. 4-5 June

Racelis, Rachel $\square$. and J.M lan S. Salas 2007. Measuring Economic Lifecycle and Flows across Population Age Groups: Data and Methods in the Application of the NTA in the Philippines: PIDS Discussion Paper Series 2007-12

Rentería, E. and M. S. Romero, G. Souto 2009 The Impact of Changes in Population Age Structure on the Economic Growth of Spain Paper presented at the $X X V I$ IUSSP Conference Marrakesh. 27 Sept - 2 October

Samuelson, Paul 1958. An exact Consumption loan model of Interest with or without the social contrivance of money, Journal of Political economy 66 [6] $467-482$

Soyibo, Adedoyin, Germano Mwabu, Olanrewaju Olaniyan and Moses Muriithi 2008. National Transfer Accounts of Kenya and Nigeria: Some Estimation Results. Paper Presented at the Western Economic Association International Conference, $\square$ awaii, June 29-3 July 2008.

Soyibo, Adedoyin, Olanrewaju Olaniyan, and Akanni O. Lawanson 2009. National health accounts of Nigeria, 2003-2005: Incorporating sub-national health accounts of 
states. Report submitted to the Federal Ministry of $\square$ ealth, Abuja.

Soyibo, Adedoyin, Olanrewaju Olaniyan, and Akanni O. Lawanson 20I0. The Structure of generational public transfer flows in Nigeria.. Chapter 25 in Population Aging and the Generational Economy Edited by Ronald Lee and Andrew Mason Edward Elgar, forthcoming?

UNDP [2009] Human Development Report Nigeria. 2008 - 2009 Achieving growth with equity; Abuja: UNDP

United Nations 2007. World Population Ageing 2007. New York: United Nations.

Willis, R. J. 1988. Life cycles, institutions and population growth: A theory of the equilibrium interest rate in an overlapping-generations model. PpI06 - I 38 in Economics of Changing Age Distributions in Developed Countries. Edited by R. D. Lee, W. B. Arthur and G. Rodgers. Oxford, Oxford University Press.

\section{Acknowledgement}

We acknowledge the financial support of Canada's International Development Research Centre [DRC $\square$ on the "Estimation African National Transfer Accounts $\square$ NTA $\square$ project" on which this paper is based. $\square$ owever, we are solely responsible for any errors in the paper. 